\title{
High Tunnels Are My Crop Insurance: An Assessment of Risk Management Tools for Small-scale Specialty Crop Producers
}

\author{
Eric Belasco, Suzette Galinato, Tom Marsh, Carol Miles, and \\ Russell Wallace
}

\begin{abstract}
High tunnels are being used by specialty crop producers to enhance production yields and quality, extend growing seasons, and protect crops from extreme weather. The tunnels are unheated, plastic-covered structures under which crops are planted directly in the soil, and they provide greater environmental protection and control than open-field production. This study uses field-level experiments to evaluate high-tunnel production. The results suggest that investments in high tunnels can provide increased profits and superior protection against adverse risks relative to crop insurance.
\end{abstract}

Key Words: crop insurance, high tunnels, risk management, specialty crop production

Agricultural production is a venture that naturally includes risk in many forms. The U.S. Federal Crop Insurance Corporation (FCIC) was established in 1938 in response to the Great Depression and Dust Bowl as a way to mitigate those risks. Beginning in 1980, crop insurance programs were expanded to include additional crops and regions. One of the major motivations behind the federal crop insurance program was ultimately to replace ad hoc disaster relief (Goodwin and Smith 1995). Secondarily, crop insurance products offer additional flexibility in providing risk protection that is non-product-specific under the WTO's "Amber Box" classification. This particular classification allows crop insurance supports to be excluded from domestic support limits as long as the de minimus level is not exceeded. Other types of Amber Box agricultural support programs, such as marketing loan benefits and average crop revenue election (ACRE), have strict limits on the amount of support across all programs with those designations but are not subject to reductions

Eric Belasco is an assistant professor in the Department of Agricultural Economics and Economics at Montana State University. Suzette Galinato is a research associate and Tom Marsh is a professor in the School of Economic Sciences at Washington State University. Carol Miles is an associate professor in Horticulture and Landscape Architecture at Washington State University. Russell Wallace is an associate professor in the Department of Horticulture Sciences at the Agrilife Research and Extension Center, Texas A\&M University. Corresponding Author: Eric Belasco = Department of Agricultural Economics and Economics - Montana State University - P.O. Box 172920 " Bozeman, MT 59717 - Phone 406.994.3706 - Email eric.belasco@montana.edu.

This material is based on work supported by the U.S. Department of Agriculture's Specialty Crop Research Initiative under award 2009-51181-05897. The authors acknowledge especially helpful comments provided by Debra Inglis, Alex Offerdahl, Vincent Smith, Tom Walters, and Annette Wszelaki. The views expressed in this paper are the authors' and do not necessarily represent the policies or views of the sponsoring agencies.

Agricultural and Resource Economics Review 42/2 (August 2013) 403-418

Copyright 2013 Northeastern Agricultural and Resource Economics Association 
under the de minimus clause. ${ }^{1}$ Currently, federal crop insurance is administered by the U.S. Department of Agriculture (USDA) Risk Management Agency (RMA) in cooperation with FCIC and private insurance companies.

Crop insurance participation expanded when subsidization rates associated with premiums increased in the 1990s and 2000s. Historically, crop insurance has been used more by growers of major grain products than by specialty crop producers. In 2009, 83 percent of grain growers and 75 percent of specialty crop growers participated in federal crop insurance programs (FCIC 2010). ${ }^{2}$

There are a few notable reasons why demand for crop insurance for fruit and vegetable products is substantially different from demand for grain. First, most specialty crops do not have well established futures and options markets, which are used to establish price guarantees for most major grain crops. The lack of a futures and options market requires a revised method for developing price guarantees, one often based on contracted prices. Second, many specialty growers produce a portfolio of crops whereas large grain producers grow mainly one or two commodities, posing a challenge for accurate rating of assorted specialty-crop-insurance products (Ligon 2011). The complexity of simultaneously insuring multiple products has inspired insurance instruments such as Adjusted Gross Revenue-Lite (AGR-Lite), a whole-farm revenue protection plan. AGR-Lite has grown relatively slowly. ${ }^{3}$ In 2009, only 3.16 percent of total liabilities related to specialty crops were associated with AGR products (FCIC 2010). Moreover, total liability associated with specialty crops in 2009 was $\$ 12.662$ billion, which is relatively small given total reported liabilities that same year for all crops of $\$ 79.575$ trillion. Third, expansion of high-tunnel use has resulted in extended and extra growing seasons (Lamont 2009), which increase demand for insurance products that cover year-round production. Many insurance products are not equipped to offer this type of coverage.

High tunnels are temporary, unheated structures similar to greenhouses and are erected over crops planted directly in the soil to provide protection from the elements and control of environmental conditions (Lamont 2009). They consist of arched or hoop-shaped frames covered with one or more layers of clear plastic. Lamont (2005) showed that high-tunnel growing systems increase yields and the quality of crops relative to open-field systems and extend early and late season production. While crop insurance provides protection against losses from adverse yields, use of high tunnels can mitigate certain risks, and, as the technology develops, will cost less to install and maintain. The tunnels might also provide a risk management tool that is more flexible than crop insurance, which is limited to covered crops in covered counties.

This study focuses on the relative impact of improved mean yields, reduced yield variability, and expanded growing seasons on profit expected under

\footnotetext{
1 Supports such as marketing loans and countercyclical programs and export credit guarantees in the United States were deemed to be in violation of World Trade Organization (WTO) compliance rules and regulations based on a dispute settlement case (DS267) initiated by Brazil against the United States (WTO 2012).

2 Participation rates are also substantially lower given that the top five specialty-crop-producing states (California, North Dakota, Washington, Florida, and Idaho) have a participation rate of 79 percent while all other states have a participation rate of 67 percent.

3 An RMA-commissioned study suggested that primary complaints about AGR products included reservations about submitting tax records for insurance, complex and intensive paperwork, low levels of coverage, lack of interest in whole-farm insurance, and delays in receiving potential indemnities (FCIC 2010).
} 
a high-tunnel system versus open-field production. If high tunnels could improve producers' yields and profits, investment in high tunnel systems could substitute for crop insurance products as a risk-management tool, especially in the case of small-scale producers. Substitutability between high tunnels and crop insurance depends primarily on how closely related they are in terms of mitigating profit risk. With this in mind, we examine expected profits between federal crop insurance and high-tunnel systems for a smallscale fruit and vegetable production system. The results of the study contribute to risk management by specialty crop producers by (i) aiding those who use or are considering using high-tunnel production systems in drafting optimal risk-management strategies, (ii) potentially providing less expensive and more comprehensive risk protection at a time when federal crop insurance products are relatively unpopular with fruit and vegetable producers, and (iii) addressing the use of high tunnels to mitigate risk in small-scale fruit and vegetable production, the first study to do so.

We next review relevant literatures with regard to high-tunnel production and risk-management products used by fruit and vegetable producers. Then, we develop a theoretical framework to evaluate producers' decisions related to choosing to invest in high tunnels and/or crop insurance to manage risk. Finally, we explain the empirical methods and data and our results. To complete this analysis, we used results from experimental field trials conducted in 2010, 2011, and 2012 for lettuce, strawberries, and tomatoes grown using hightunnel and open-field systems in Knoxville, Tennessee, Lubbock, Texas, and Mount Vernon, Washington. The field experiments were funded by a USDA transdisciplinary research and extension project on biodegradable mulches for specialty crops produced under protective covers (National Institute of Food and Agriculture's (NIFA's) Specialty Crop Research Initiative (SCRI) Program 2009-02484). We use split block data to analyze differences in yield, quality, and planting/harvesting for the two production systems. We combine those results with enterprise crop budgets that were compiled for the state of Washington (Galinato, Miles, and Ponnaluru 2012).

\section{Specialty Crop Risk Management}

The main forms of crop insurance for fruit and vegetable growers are actual production history (APH), fixed dollar plan (DOL), catastrophic coverage (CAT), average revenue history (ARH), and adjusted gross income (AGR-Lite) plus a noninsurance crop disaster-assistance program (NAP). APH insures producers' yields against weather-related losses caused by drought, excessive moisture, hail, wind, frost, insects, disease, and other unavoidable perils. While high tunnels can block some of those elements, extreme weather such as high winds, hail, and flooding can compromise the tunnels and thus the plants beneath them, leading to losses that would not be covered without crop insurance. Coverage levels under the various plans range from 50 percent to 85 percent of the established yield guarantee. For APH, the producer selects an amount of insurance between 55 percent and 100 percent of the crop price established by RMA. In the event of a loss, the indemnity pays the established crop price for the difference in quantity between the insured yield amount and the actual yield. In contrast, the DOL policy protects against declining value due to damages that reduce yields. The amount of insurance is based on the cost of growing a crop in a specific area. A loss occurs when the annual crop value is less than 
the amount of insurance. The maximum dollar amount of insurance is stated in the actuarial document. The insured may select a percentage of the maximum dollar amount equal to catastrophic coverage or purchase additional coverage levels. Our research focuses on the APH product.

The number of specialty crops covered by insurance increased 29 percent from 1998 to 2003 (RMA 2004). One of the main points of emphasis within the 2000 Agricultural Risk Protection Act (ARPA) was expansion of crop insurance offerings to commodities previously underserved, such as fruits and vegetables. During the 2012 crop year, 40 specialty crops $^{4}$ were covered by individual insurance plans (FCIC 2012).

High participation rates for many crop insurance products are attributed primarily to substantial premium rate subsidies, and the cost of high tunnels is also subsidized. A recent pilot project initiated by the USDA National Resources Conservation Service (NRCS) and involving the Environmental Quality Incentives Program (EQIP), the EQIP Organic Initiative, and the Agricultural Management Assistance Program provides subsidies that effectively cut the cost of high tunnels by half or more. In one year, this initiative resulted in funding of more than 2,400 seasonal high tunnels in 43 states (NRCS 2011). State-based initiatives may further reduce the upfront cost of high-tunnel construction (e.g., the Tennessee Agricultural Enhancement Program matches USDA funds for new tunnel construction in Tennessee (State of Tennessee 2010)). While past research on high-tunnel systems has reported improvements in yields and quality as well as season extension (Lamont 2005), evidence of the overall economic potential of high tunnels is ambiguous because profitability hinges on labor efficiency, capital investments, and the availability of financial credit (Waterer 2003). Several recent studies analyzed factors related to the profitability of high tunnels for small farmers (Conner 2008, Donnell, Biermacher, and Upson 2011, Galinato, Miles, and Ponnaluru 2012).

The fixed cost of constructing high tunnels is significant and varies by location since local weather conditions can dictate the type of tunnel required and local labor markets can affect construction costs (Coolong 2010, Jimenez, Walser, and Torres 2005, Blomgren and Frisch 2007). For example, tunnels in an area that routinely gets high winds could require framed reinforcement.

After the tunnels have been constructed, growers maximize their return on investment through season extension and increased crop quality and quantity. Several case studies cited in Blomgren and Frisch (2007) demonstrated that high-tunnel crops are associated with an early harvest price premium, longer shelf life, higher product quality, and more stable yields in the event of adverse weather.

High tunnels effectively reduce adverse-profitability risk associated with specialty crop production in two primary ways: (i) the tunnel structure mitigates adverse yield risk by blocking heavy winds and rains and by reducing drought-related sun exposure; and (ii) since temperatures within tunnels are higher than temperatures outside, growers can plant earlier in the season, leading to earlier and more frequent harvests. For example, Wallace et al. (2011) demonstrated that strawberries can be grown in Tennessee over the winter and Wallace et al. (2012) showed that lettuce can be grown earlier in Tennessee and Texas.

\footnotetext{
4 The specialty crop designations used here are based on www.ams.usda.gov/AMSv1.0/ scbgpdefinitions.
} 
The use of crop insurance as a means of risk management has become an important component for most U.S. agricultural production. Small-scale farms pose a challenge to insurance agencies since their production systems require a different type of insurance than is demanded by larger grain producers. The methodology detailed in the next section provides a framework from which to examine the feasibility of using a high-tunnel production system to manage risk for a small-scale specialty crop producer.

\section{Methodology}

In this analysis, we evaluate two crop systems, high tunnels and open fields, for production of fresh tomatoes, strawberries, and lettuce. While no specific federal crop insurance offerings cover strawberries and lettuce, those crops can be insured under two umbrella products that are based on adjusted gross revenue (AGR), AGR-Lite and AGR. ${ }^{5}$ Fresh tomatoes, on the other hand, can be insured using APH and DOL plans.

To evaluate the two systems, we assess the profitability of a single plot (defined as 1,000 square feet in size) ${ }^{6}$ that is planted with a single crop and compare yields with and without a high-tunnel system. ${ }^{7}$ When no crop insurance is used, the profit $(\pi)$ from a single plot is determined by

$$
\pi_{N I}=P \times Q-T C
$$

where $N I$ denotes the lack of crop insurance, $P$ is the average output price in dollars per kilogram for the harvest period, $Q$ is the quantity produced in kilograms $(\mathrm{kg})$ per plot during a single harvest year, and TC is the total cost of production associated with the plot, which includes both fixed costs $(F C)$ and variable costs $(V C)$. Under high-tunnel production, there is a significant, one-time, fixed cost. The cost includes an annualized amount associated with construction of the tunnel $(a)$ - the fixed cost of the tunnel divided by the number of years in the life of the tunnel (usually ten years for the metal parts and skeleton and three years for the poly covering). In developing this framework, we assume four scenarios in which a producer grows a single product: (i) no insurance and no high tunnel, (ii) a high tunnel and no insurance, (iii) insurance and no high tunnel, and (iv) insurance and a high tunnel. When no high tunnel is used, crops are grown in an open field. Using equation (1), we derive expected prices, yields, and costs with and without a tunnel when no insurance is used via the following relationships:

$$
\begin{aligned}
& E\left(P_{H T}\right)=\alpha E\left(P_{N H T}\right) \\
& E\left(Q_{H T}\right)=\kappa E\left(Q_{N H T}\right)
\end{aligned}
$$

5 RMA began the ARH Strawberry Pilot Program in 2012.

6 Yields are normalized to 1,000 square feet because Lubbock, Texas, and Nashville, Tennessee, used high tunnels measuring 29 by 29 feet (841 square feet) and Mount Vernon, Washington, used tunnels that measured 20 by 96 feet (1,920 square feet).

7 The experimental design assigned each of the three crops (strawberries, tomatoes, and lettuce) to eight separate plots of different cultivars that were replicated in four high-tunnel and four open-field sites. Since we report results for production with and without high tunnels, the overall yield for each tunnel is assumed to be equal to growing a single crop on a single plot. 


$$
F C_{H T}=F C_{N H T}+a
$$

where HT denotes a high tunnel, NHT denotes no high tunnel, $\alpha>1, \kappa>1$, and $a>0$. The parameters $\alpha$ and $\kappa$ can be interpreted as multiplier effects on average prices and yields respectively. Thus, expected profits in scenarios with no insurance are calculated by ${ }^{8}$

$$
E\left(\pi_{N I, H T}\right)=\alpha E\left(P_{N H T}\right) \times \kappa E\left(Q_{N H T}\right)-V C-\left(F C_{N H T}+a\right)
$$

for production with a high tunnel and by

$$
E\left(\pi_{N I, N H T}\right)=E\left(P_{N H T}\right) \times E\left(Q_{N H T}\right)-V C-F C_{N H T}
$$

for production without a tunnel.

Inclusion of crop insurance for a single crop augments equation (1) as follows:

$$
\pi_{I}=P \times Q+I(\delta)-\gamma-T C
$$

where $I(\delta)$ is the indemnity payout, which is based on the level of coverage $(\delta)$ such that $I(\delta)=P_{G} \times \operatorname{Max}\left(\delta Y_{A P H}-Y, 0\right) . P_{G}$ is the guaranteed price determined by RMA, $Y_{A P H}$ is the standard yield set by APH based on historical outcomes, and $Y$ is the observed yield. Given that price guarantees are often based on expected prices at the time of planting, we assume that $E(P)=P_{G^{*}} P_{G}$ is a fixed variable, but the actual price received is a random variable. ${ }^{9}$ Additionally, $\gamma$ is the premium paid or the cost of insurance, which, in the case of federal crop insurance, is the actuarially fair premium rate (equal to the expected loss) minus the federally mandated subsidy. The subsidy is based on the level of coverage and is a percentage of the premium.

If the price guarantee $\left(P_{G}\right)$ is assumed to equal $E\left(P_{N H T}\right)$ (the expected price) from equation (7), the expected profit with insurance is

$$
E\left(\pi_{l, H T}\right)=E\left(P_{N H T}\right) \times\left[\alpha \kappa E\left(Q_{N H T}\right)+E\left\{\operatorname{Max}\left(\delta\left(\kappa Y_{A P H}\right)-Y, 0\right)\right\}\right]-\gamma-V C-(F C+a)
$$

for high-tunnel production and

$$
E\left(\pi_{I, N H T}\right)=E\left(P_{N H T}\right) \times\left[E\left(Q_{N H T}\right)+E\left\{\operatorname{Max}\left(\delta Y_{A P H}-Y, 0\right)\right\}\right]-\gamma-V C-F C
$$

for open-field production. We are interested in differences in expected profits as determined by these equations. For example, the difference in expected profit from with-tunnel and no-tunnel production when a producer foregoes insurance can be characterized as $E\left(\pi_{N I, H T}\right)-E\left(\pi_{N I, N H T}\right)$. In this case, the additional revenue generated by higher yields and prices from high-tunnel production must outweigh the fixed costs associated with constructing the tunnels for the tunnels to improve the expected profit. ${ }^{10}$ With crop insurance

\footnotetext{
8 We assume that prices and yields are independently drawn from separate distributions.

9 Harvest price options exist in some crop insurance products. The price guarantee adjusts in response to price increases throughout the growing period. However, this option is not available for specialty crops.

10 It is likely that a longer growing season would result in an increase in variable costs of production; however, a lack of available data prevents us from identifying a multiplier for this value.
} 


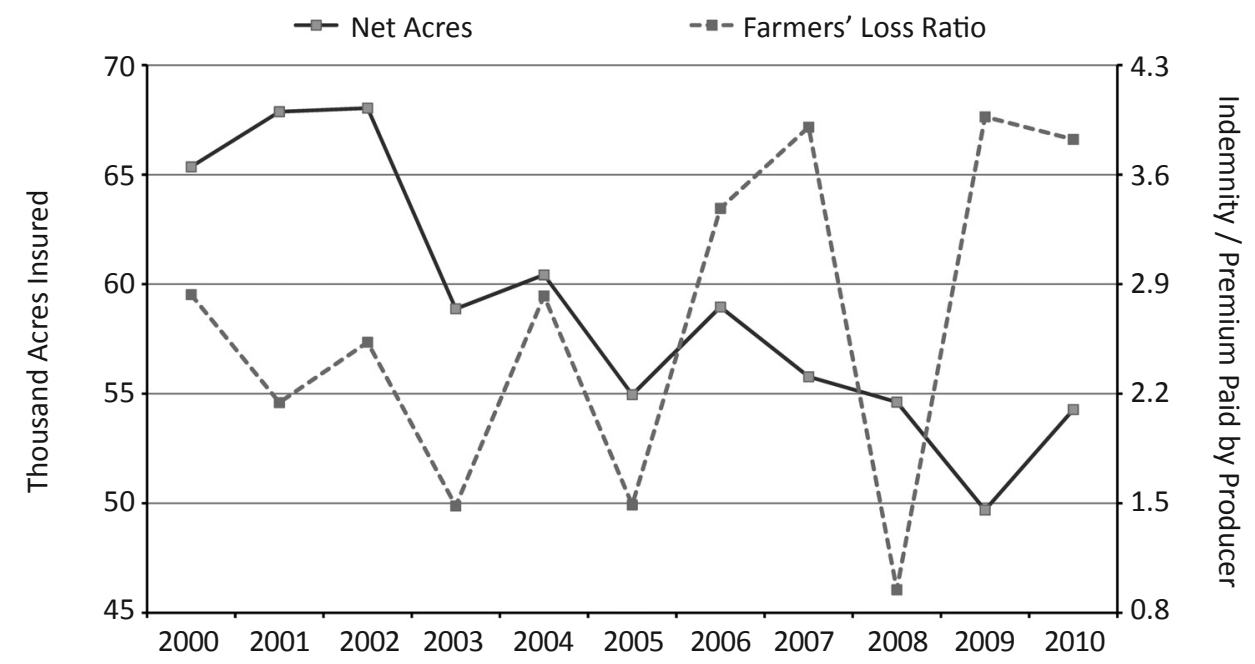

Figure 1. Fresh Tomatoes: Insured Net Acres and Subsidy-adjusted Loss Ratios (APH and DOL)

Source: RMA (2012).

and without high tunnels, the amount expected from the insurance indemnity must be greater than the premium paid by the producer for this scenario to be the more profitable enterprise. Notice that the producer is assumed to be risk-neutral and focused on maximizing expected profit. ${ }^{11}$ We also assume, based on historical data shown in Figure 1, that the average subsidy-adjusted loss ratio for fruits and vegetables is 2.0. The ratio is calculated as indemnities paid to the farmer divided by the total premium less any premium subsidy. A subsidy-adjusted loss ratio of 2.0 means that farmers receive twice as much in indemnities as they pay in premiums.

\section{Empirical Application}

In this empirical application, important parameters are estimated and used to compute the expected profitability of each of the four scenarios previously described. The primary areas to be estimated are (i) the price premium received by early-to-market producers who use high tunnels $(\alpha)$, (ii) additional yields from high-tunnel production ( $\mathrm{k}$ ), (iii) the annualized cost of tunnel construction $(a)$, and (iv) the premium paid for insurance $(\gamma)$. We first explain how each of the four parameters was estimated and then determine expected profitability for each scenario based on the parameter estimates.

\section{Price Premium}

To put the price premium into perspective, we show monthly prices for tomatoes and strawberries in Figures $2 \mathrm{a}$ and $2 \mathrm{~b}$. While there is a slight upward trend, especially over the last couple of years, it is clear that seasonal features

11 While an assessment of variability differences between high-tunnel and traditional producers is desirable, data limitations prevent such a study at this time. Thus, our focus is on differences in expected profits while discussing issues associated with higher moments. 
soak up most of the monthly variability in prices. This systematic seasonal component allows high-tunnel producers to plan to market earlier or later than the typical harvest season and thus receive a price premium. In Figure 3, we provide seasonal features using normalized monthly prices for strawberries, tomatoes, and lettuce obtained from USDA's National Agricultural Statistics Service (NASS). Strawberries are particularly interesting in that a significant price premium comes from marketing them one month earlier, particularly in January, February, and March. For example, if strawberry growers market in March instead of April, they can expect a 24.6 percent higher price.

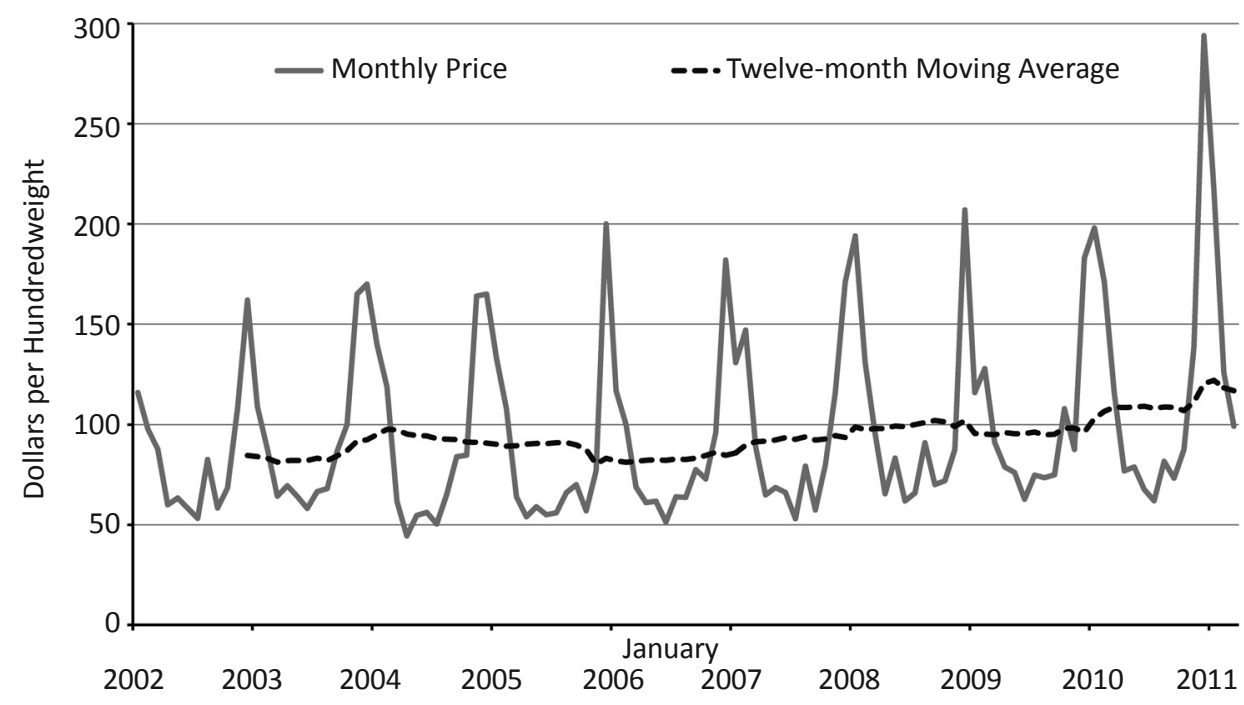

Figure 2a. Monthly Fresh Strawberry Prices over Time

Source: NASS (2012)

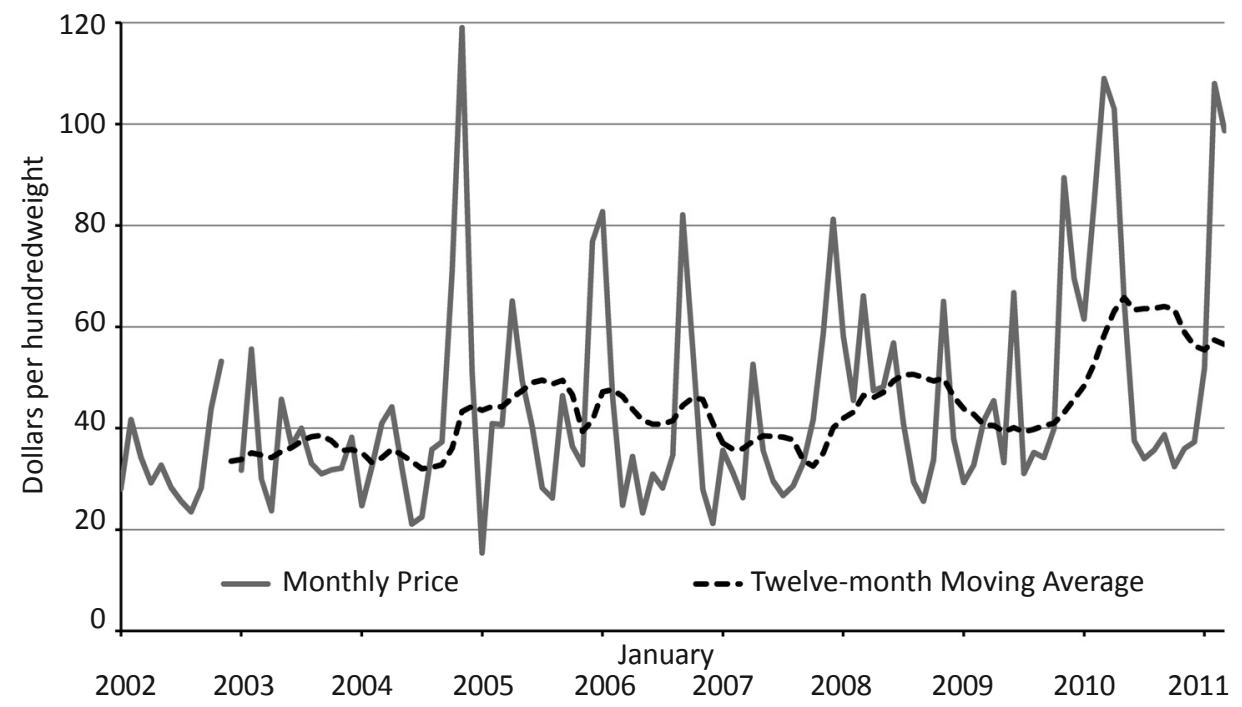

Figure 2b. Monthly Fresh Tomato Prices over Time

Source: NASS (2012) 


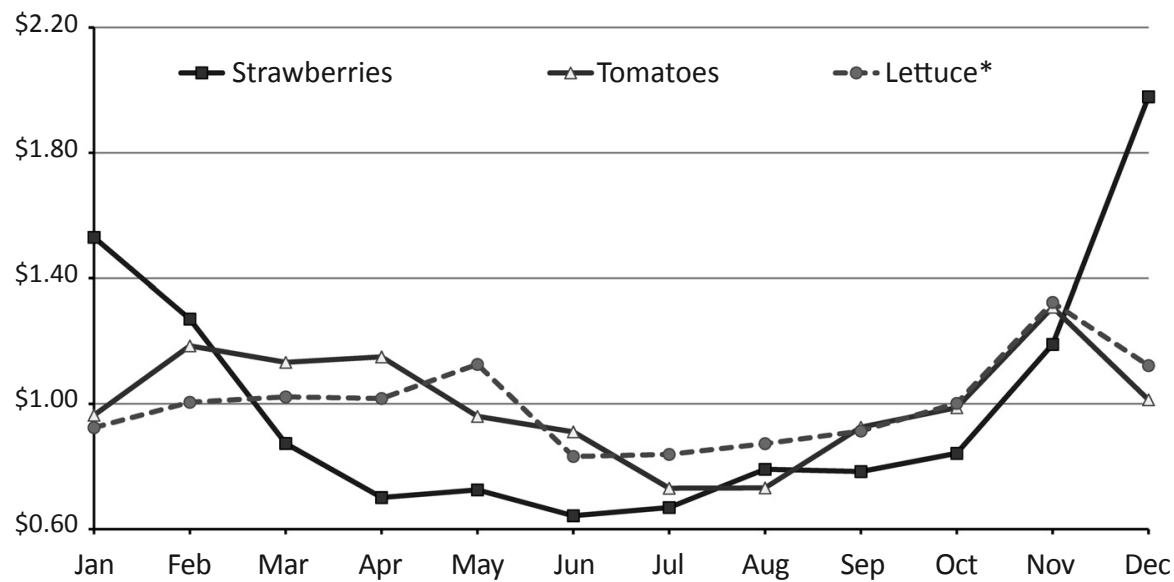

Figure 3. Monthly Indexed National NASS Prices Received in the Fresh Market, 2002-2011

Notes: ${ }^{*}$ Lettuce prices include 2006 and 2008 through 2011 only. Annual mean $=1.0$. Source: NASS (2012).

The magnitude of the price premium has a substantial impact on revenue and can decrease the time needed to recoup the initial cost of tunnel construction.

Average annual prices $(P)$ received by a grower can be computed as

$$
P=\sum_{m=1}^{12} \omega_{m} P_{m}
$$

where $\omega_{m}$ is the share of the annual marketed yield produced in month $m$ such that $\sum_{m=1}^{12} \omega_{m}=1$ and $P_{m}$ is the price in month $m$ when accounting for seasonal premiums. While $P_{m}$ is assumed to be identical for open-field and high-tunnel crops, $\omega_{m}$ is different given the longer growing season available to high-tunnel growers. Average annual prices received by open-field and high-tunnel growers are compared to estimate $\alpha$. However, the price is heavily influenced by the growing location. As an example, we provide percentages of marketable yields by month for Texas in Table 1 .

Table 1 demonstrates that a high-tunnel system results in earlier marketable yields for fall-transplanted strawberry varieties in Texas, allowing the producer to sell strawberries in months in which a substantial premium is earned (November through February). Given the shares of marketable yield by month and the indexed monthly prices shown in Figure 3, $\alpha$ equals 1.229, meaning that the average price received under the high-tunnel system is 22.9 percent higher than the average price from open-field operations. In our experiments conducted in Texas and Tennessee, high-tunnel systems have successfully expanded the strawberry growing season. High-tunnel crops were harvested in Tennessee in November and December and again in April, May, and June. The additional harvest season is in December and January, months with particularly high price premiums. Our experiments in Washington showed essentially no price premium given the poor performance of some of the June-bearing varieties. In that case, larger high-tunnel yields were realized in June rather than July but yields during fall months, when price premiums increase again, were smaller. The result was $\alpha \approx 1$, meaning that no price premium is realized. 
Table 1. Total Marketable Strawberry Yields from Field Experiments

\begin{tabular}{|c|c|c|c|c|c|c|}
\hline \multirow[b]{3}{*}{ Month } & \multicolumn{6}{|c|}{ Percent of Total Yield } \\
\hline & \multicolumn{2}{|c|}{ Texas } & \multicolumn{2}{|c|}{ Washington } & \multicolumn{2}{|c|}{ Tennessee } \\
\hline & $\begin{array}{l}\text { Open } \\
\text { Field }\end{array}$ & $\begin{array}{c}\text { High } \\
\text { Tunnel }\end{array}$ & $\begin{array}{l}\text { Open } \\
\text { Field }\end{array}$ & $\begin{array}{c}\text { High } \\
\text { Tunnel }\end{array}$ & $\begin{array}{l}\text { Open } \\
\text { Field }\end{array}$ & $\begin{array}{l}\text { High } \\
\text { Tunnel }\end{array}$ \\
\hline March & 6 & 33 & 0 & 0 & 0 & 34 \\
\hline April & 85 & 40 & 0 & 0 & 57 & 49 \\
\hline May & 9 & 14 & 0 & 0 & 22 & 2 \\
\hline June & 0 & 0 & 18 & 27 & 21 & 5 \\
\hline July & 0 & 0 & 7 & 6 & 0 & 0 \\
\hline August & 0 & 0 & 26 & 27 & 0 & 0 \\
\hline September & 0 & 0 & 40 & 31 & 0 & 0 \\
\hline October & 0 & 0 & 9 & 9 & 0 & 0 \\
\hline November & 0 & 2 & 0 & 0 & 0 & 0 \\
\hline December & 0 & 5 & 0 & 0 & 0 & 9 \\
\hline January & 0 & 2 & 0 & 0 & 0 & 1 \\
\hline February & 0 & 4 & 0 & 0 & 0 & 0 \\
\hline
\end{tabular}

Table 2. Total Marketable Yields by Location and Year for Experimental Field Trials

\begin{tabular}{|c|c|c|c|c|c|c|}
\hline \multirow[b]{3}{*}{ Site } & \multicolumn{4}{|c|}{ Kilograms per Plot } & \multirow{2}{*}{\multicolumn{2}{|c|}{$\begin{array}{l}\text { Percent Gain in } \\
\text { High Tunnel }\end{array}$}} \\
\hline & \multicolumn{2}{|c|}{2010} & \multicolumn{2}{|c|}{2011} & & \\
\hline & $\begin{array}{c}\text { High } \\
\text { Tunnel }\end{array}$ & $\begin{array}{l}\text { Open } \\
\text { Field }\end{array}$ & $\begin{array}{c}\text { High } \\
\text { Tunnel }\end{array}$ & $\begin{array}{l}\text { Open } \\
\text { Field }\end{array}$ & 2010 & 2011 \\
\hline \multicolumn{7}{|l|}{ Tomatoes } \\
\hline Knoxville, Tennessee & 41.7 & 3.6 & 91.3 & 48.0 & $1,070.0$ & 90.6 \\
\hline Lubbock, Texas & 64.6 & 10.3 & $60.8^{\mathrm{a}}$ & $0.0^{\mathrm{a}}$ & 524.1 & NA \\
\hline Mt. Vernon, Washington & 6.5 & 0.8 & 32.9 & 11.4 & 681.3 & 188.6 \\
\hline \multicolumn{7}{|l|}{ Lettuce } \\
\hline Knoxville, Tennessee & $30.4^{\mathrm{b}}$ & $60.6^{\mathrm{b}}$ & 75.1 & 47.9 & -49.8 & 56.8 \\
\hline Lubbock, Texas & 119.4 & 110.1 & 125.1 & 112.6 & 8.4 & 11.1 \\
\hline Mt. Vernon, Washington & $26.1^{\mathrm{b}}$ & $32.7^{b}$ & 27.2 & 26.3 & -19.9 & 3.8 \\
\hline \multicolumn{7}{|l|}{ Strawberries } \\
\hline Knoxville, Tennessee & $3.2^{\mathrm{c}}$ & $0.2^{\mathrm{c}}$ & 44.1 & 11.5 & $1,400.0$ & 282.5 \\
\hline Lubbock, Texas & $0.0^{\mathrm{d}}$ & $0.0^{\mathrm{d}}$ & 72.2 & 10.5 & NA & 589.8 \\
\hline Mt. Vernon, Washington & 12.9 & 12.6 & 21.0 & 20.1 & 2.5 & 4.4 \\
\hline
\end{tabular}

${ }^{a}$ Indicates that marketable yields were impacted by excessive heat and dry conditions.

${ }^{\mathrm{b}}$ Indicates that marketable yields were impacted by tip-burn and bolting.

${ }^{\mathrm{c}}$ Indicates that yields were impacted by hail damage.

${ }^{\mathrm{d}}$ Indicates that yields were impacted by flooding and excessive rainfall. 


\section{Yield Premium}

High-tunnel producers also collect on their investment through greater yields. While crop varieties respond differently to tunnel systems, yields for all of the commodities considered in this study were greater (across varieties and commodities) under tunnel production than under open-field production. Larger yields increase revenue even when the produce is marketed in traditional and nontraditional months. Table 2 illustrates the difference in total marketable yields by production system and crop.

With the exception of yields for lettuce in 2010, which were affected mainly by tip-burn and bolting, yields for a high-tunnel system were greater than yields for an open-field system. It is clear that the yield multiplier, $\kappa$, is greater than one, which implies that yields are higher in high-tunnel systems. It is less clear what the level of yield improvement is given the large degree of variability in results.

A few notable issues are relevant to the discussion of yields. Tomato yields were more than twice as high in all but one of the high-tunnel cases. Additionally, strawberry yields have been at least three times greater under high-tunnel production for two years. However, the yields in 2011 were more reliable because of a change in planting from spring in 2010 to fall in 2011.

\section{Cost of High Tunnels}

As previously mentioned, the cost of high-tunnel construction varies with the size and complexity of the structure. It also depends on whether the grower constructs the high tunnel or purchases a kit from a commercial source. Based on cost estimates contained in Galinato, Miles, and Ponnaluru (2012) and Nennich and Johnson (2004), we assume a total fixed cost for the structure (including interest and depreciation) of about $\$ 212$ per year. An additional annual variable cost of approximately $\$ 278$ is included to cover maintenance of tunnel production systems.

\section{Insurance Premium}

USDA requires RMA premiums to be actuarially fair. Producers then receive a subsidy to reduce the cost of insurance. Actuarial fairness implies that expected losses equal the premium rate; in this case, $E\left(P_{N H T}\right) \times E\left\{\operatorname{Max}\left(\delta Y_{A P H}-Y, 0\right)\right\}=\gamma$. Thus, the loss ratio (indemnities divided by the premium) is 1.0 on average. Based on data from RMA (2012), loss ratios for specialty crop insurance products have historically been closer to 0.66 . For every dollar paid in premiums, 66 cents was paid back to the farmer as indemnities. However, that rate ignores the fact that the federal government pays more than 60 percent of the premium rate. Consequently, the subsidy-adjusted loss ratio, which equals indemnities collected by the farmer divided by the premium the farmer pays, is closer to 2.0 (as shown in Figure 1). Thus, for every dollar farmers pay into crop insurance, they can expect to receive twice that amount in indemnities.

Since the parameters in the profit equations focus exclusively on the amount a producer pays for insurance (after subsidies), $E\left(P_{N H T}\right) E\left\{\operatorname{Max}\left(\delta Y_{A P H}-Y, 0\right)\right\}=$ $2 \gamma$, which implies that crop insurance leads to a greater expected profit when high tunnels are not used (i.e., $\left.E\left(\pi_{I, N H T}\right)-E\left(\pi_{N I, N H T}\right)>0\right)$. The expected value of the censored distribution can be advanced one step such that 


$$
\begin{aligned}
& E\left\{\operatorname{Max}\left(\delta Y_{A P H}-Y, 0\right)\right\}=\Phi\left(\frac{\delta Y_{A P H}-Y}{\sigma}\right)\left[\delta Y_{A P H}-Y+\sigma \lambda\right] \\
& \text { where } \lambda=\phi\left(\frac{\delta Y_{A P H}-Y}{\sigma}\right) / \Phi\left(\frac{\delta Y_{A P H}-Y}{\sigma}\right)
\end{aligned}
$$

based on Greene (2011, p. 847). ${ }^{12}$

\section{Expected Profitability}

Table 3 describes the assumptions made in each scenario and reports our results for differences in profitability. Results from the field experiments provided information that was more reliable regarding strawberry trials, which are the focus of this analysis.

The scenarios assume a coverage level of 75 percent and a standard deviation in yield of 75. Premiums for high-tunnel production are substantial when prices and yields rise significantly above average, demonstrating the importance of yield and price in making a high-tunnel investment profitable. For example, operations more reasonably capture a price premium when they are located near large consumer markets for fresh fruits and vegetables. Price premiums also likely vary significantly across the United States. Yields are an important factor in the profitability of high-tunnel systems. Note, also, that estimated price premiums are likely to be smaller if additional high-tunnel adoption is observed since a larger supply would hit the market during off-season periods.

Both yield and price premiums are extremely important in retrieving large profit gains, as shown in Table 3. When yields inside and outside of a high tunnel are the same, the price premium alone cannot offset the initial investment. ${ }^{13}$ This fact illustrates the importance of understanding these two components before investing in high tunnels.

Given our emphasis on high tunnels for risk management, it is important to compute differences in yields. Here, we assume that yields are random draws from two distributions, $Y_{N H T} \sim N\left(E\left(Q_{N H T}\right), \sigma\right)$ and $Y_{H T} \sim N\left(\kappa E\left(Q_{N H T}\right), v \sigma\right)$ where $\alpha=1.25$ and $v=0.75$. In these distributions, $\kappa$ remains the yield premium generated by a high-tunnel system and $v$ is the reduction in standard deviations for yield that comes from the more controlled environment provided by tunnels. In open-field experiments, $v=0.75$, meaning that high-tunnel yields are estimated to have standard deviations that are 25 percent smaller than deviations for open-field production. We also assume that the expected yield, $E\left(Q_{N H T}\right)$, is $424.03^{14} \mathrm{~kg}$ per plot. In scenarios in which insurance is purchased,

\footnotetext{
12 The assumption that indemnities are distributed according to a censored normal arises from the assumption that yields are normally distributed. Many researchers have disputed the assumption of normality for yields (see Goodwin and Ker 2001), mainly on grounds of excessive negative skewness and kurtosis. We acknowledge that, when a yield distribution has negative skewness, assuming a normal distribution will decrease the mean of the distribution. However, given that we are only interested in differences between mean values, our results should not be significantly impacted by assuming other commonly used distributions, such as beta or triangular.

${ }^{13}$ We do not include premiums that might be given to suppliers who have recognized longer shelf life for products grown in a high tunnel. Some grocers may limit purchases to high-tunnel products since organic production practices can also be employed, but tunnel production may expand access to markets not available under the alternative production system.

14 The expected yields are based on NASS national tomato yield averages for 2007 through 2011 that we converted to conform to kilograms per plot.
} 
Table 3. Differences in Expected Profitability for Each Scenario

\begin{tabular}{|c|c|c|c|c|c|}
\hline Parameter & Average & $\begin{array}{l}\text { High Price } \\
\text { Premium }\end{array}$ & $\begin{array}{l}\text { Low Price } \\
\text { Premium }\end{array}$ & $\begin{array}{c}\text { High } \\
\text { Yield } \\
\text { Premium } \\
\end{array}$ & $\begin{array}{c}\text { Low } \\
\text { Yield } \\
\text { Premium } \\
\end{array}$ \\
\hline $\begin{array}{l}\text { High-tunnel cost per year } \\
\text { (dollars per plot) }\end{array}$ & $\$ 500$ & $\$ 500$ & $\$ 500$ & $\$ 500$ & $\$ 500$ \\
\hline Price premium $(\alpha)$ & 1.25 & 1.50 & 1.00 & 1.25 & 1.25 \\
\hline Yield premium ( $(\kappa)$ & 1.50 & 1.50 & 1.50 & 2.00 & 1.00 \\
\hline $\begin{array}{l}\text { Average price } \\
\text { (no tunnels) (dollars per kg) }\end{array}$ & $\$ 1.93$ & $\$ 1.93$ & $\$ 1.93$ & $\$ 1.93$ & $\$ 1.93$ \\
\hline $\begin{array}{l}\text { Average yield } \\
\text { (no tunnels) (kg per plot) }\end{array}$ & 504.20 & 504.20 & 504.20 & 504.20 & 504.20 \\
\hline \multicolumn{6}{|c|}{ Differences in Expected Profits Relative to No High Tunnel and No Insurance } \\
\hline High tunnels, no insurance & $\$ 351.05$ & $\$ 715.78$ & $-\$ 13.69$ & $\$ 958.94$ & $-\$ 256.84$ \\
\hline Insurance, no high tunnels & $\$ 1.39$ & $\$ 1.39$ & $\$ 1.39$ & $\$ 1.39$ & $\$ 1.39$ \\
\hline High tunnels with insurance & $\$ 352.43$ & $\$ 717.17$ & $-\$ 12.30$ & $\$ 960.32$ & $-\$ 255.46$ \\
\hline
\end{tabular}

Note: Highlighted numbers indicate a changed input.

the average actual indemnity is $\$ 2.77$ per plot. This value is approximately equal to expected losses and would equal an actuarially fair premium rate. Recall that approximately 60 percent of this rate is subsidized depending on the coverage level. If one assumes a 60 percent subsidy rate, the cost of insurance per plot $(\gamma)$ is approximately $\$ 1.38$. The difference between the average actual indemnity (\$2.77) and the cost of insurance ( $\$ 1.38)$ is roughly equal to $\Delta_{I, N H T}=1.39$.

Given a standard deviation in yield of 75 (12 percent of the mean), an indemnity would be received only 6.5 percent of the time under 75 percent coverage, which provides a yield guarantee of $378 \mathrm{~kg}$ when the average yield is $504 \mathrm{~kg}$.

\section{Discussion and Conclusions}

Past studies have indicated that high-tunnel systems can increase yields (Median et al. 2009), reduce yield variability, and allow for earlier marketing, all of which translate to price premiums (Blomgren and Frisch 2007). This is the first study to identify the impacts from advantages of a high-tunnel system on expected profitability with crop insurance as an alternative.

Our research suggests several future avenues of investigation. First, the substitutability between high-tunnel production and crop insurance as a risk management strategy largely depends on the ability of each to limit exposure to downside income risk. While an empirical assessment of the two production systems would require a large data sample of annual yields and prices, there is anecdotal evidence in this study that high tunnels effectively curtail downside weather events. For example, 2011 resulted in record low rainfall in Lubbock, Texas-5.9 inches, mostly in winter, versus the county average of 18.7 inches of rainfall per year between 1911 and 2010 (National Oceanic and Atmospheric 
Administration 2013). In 2011, tomato and strawberry crops would have qualified for indemnities through crop insurance but high-tunnel outcomes were in line with the preceding year, indicating that the tunnels mitigated the risk associated with lack of rain. Consequently, our experiments suggest that high tunnels can mitigate yield shortfalls in addition to increasing yields in years of more moderate weather.

It would be interesting to evaluate the same decisions under risk-aversion. Such a study would require additional years of yield outcomes to more accurately compare standard deviations in yields. While our results demonstrate that high tunnels can increase expected profit and reduce yield variability, additional data are needed to provide a more thorough assessment.

Adverse selection is likely to be a limiting factor when considering joint use of crop insurance and high tunnels to manage risk. The yield distribution for hightunnel producers is likely to be substantially different from the distribution for traditional producers. Adverse selection is limited to some extent in that premium rates reflect the reduced risk inherent to high-tunnel crop systems. Future research could focus on estimating these distributional assumptions for high-tunnel crop systems and for the implied premium rating.

Given the ongoing commitment from USDA to analyze and fund high-tunnel production through NRCS (NRCS 2011), novice producers establishing hightunnel systems will be an expanding demographic in agricultural production. Our results are important and timely in that they provide strategies for managing risk when high tunnels are used. This research also examines the potential role of federal subsidy programs in supporting existing specialty crop enterprises at a time when discussions of the farm bill and federal deficit issues are under joint consideration.

In theory, a risk-averse individual clearly prefers to have insurance given the greater expected payouts and reduced variance under insurance. Two caveats are important. First, participation by specialty crop producers in federal crop insurance programs (a rate of around 75 percent) is not consistent with this premise even with a heavily subsidized product. Second, when one compares expected gains from insurance to expected gains from high tunnels, especially when the producer is confident that those yield and price premiums can be obtained, it is clear that positive profits can be expected in both the short term and the long term under high-tunnel systems. Additionally, NRCS subsidizes about 50 percent of the initial cost of installing high tunnels and state initiatives sometimes match those subsidies, none of which is accounted for in this study. While crop insurance provides a safety net for farmer revenue, high tunnels shift and shrink distributions of yields while positively affecting price premiums. This outcome effectively aids in managing risk by upshifting potential profit - the upside potential becomes more likely. In addition, at a time when government support payments are under fire from the public, high tunnels provide a mechanism by which small-scale producers can more effectively use fields to maximize profit without the use of government payments.

Greater use of high tunnels may reduce off-season price premiums as growing seasons expand. However, premiums may still exist as longer shelf life has been realized in past high-tunnel experiments. Access to year-round markets presents an important advantage of high-tunnel production as state-level initiatives push for better connections between agricultural production and rural consumers through school-lunch farmers' markets and farm-to-hospital programs. High-tunnel production is likely to strengthen such linkages. This 
study demonstrates that high tunnels present a risk management resource for producers even in the absence of such incentives.

\section{References}

Blomgren, T., and T. Frisch. 2007. "High Tunnels: Using Low Cost Technology to Increase Yields, Improve Quality, and Extend the Season." Center for Sustainable Agriculture, University of Vermont. Available at www.uvm.edu/sustainableagriculture/Documents/ HighTunnels.pdf (accessed April 2011).

Conner, D. 2008. "Does Year-round Hoop-house Production Pencil Out?" Presentation at Oregon State University Extension Small Farms Conference, Corvallis, Oregon.

Coolong, T. 2010. "Low Cost High Tunnel Construction." Article 18356, eXtension Initiative, Lincoln, NE. Available at www.extension.org/pages/18356/low-cost-high-tunnelconstruction (accessed May 29, 2012).

Donnell, J., J.T. Biermacher, and S. Upson. 2011. "Economic Potential to Using High Tunnel Hoop Houses to Produce Fruits and Vegetables." Selected Paper, Southern Agricultural Economics Association Annual Meeting, Corpus Christi, TX.

Federal Crop Insurance Corporation. 2010. Report to Congress: Specialty Crop Report. Available at www.rma.usda.gov/pubs/2010/specialtycrop.pdf (accessed on May 29, 2012).

— 2012. "Crop Year Statistics for 2012." Available at www3.rma.usda.gov/apps/sob/ current_week/crop2012.pdf (accessed on September 12, 2012).

Galinato, S.P., C.A. Miles, and S.S. Ponnaluru. 2012. "2011 Cost Estimates of Producing Tomatoes in High Tunnel in Washington." Fact Sheet FS080E, Washington State University Extension, Pullman, WA

Goodwin, B.K., and A.P. Ker. 2001. "Modeling Price and Yield Risk." In R.E. Just and R.D. Pope, eds., A Comprehensive Assessment of the Role of Risk in U.S. Agriculture. Norwell, MA: Kluwer Academic Publishers.

Goodwin, B.K., and V.H. Smith. 1995. The Economics of Crop Insurance and Disaster Aid. Washington, DC: AEI Press.

Greene, W.H. 2011. Econometric Analysis ( $7^{\text {th }}$ edition). Upper Saddle River, NJ: Prentice Hall.

Jimenez, D., R. Walser, and R. Torres. 2005. "Hoop House Construction for New Mexico: Twelve-foot by Forty-foot Hoop House." Circular 606, New Mexico State University Cooperative Extension Service, Las Cruces, NM. Available at www.hightunnels.org/PDF/ Hoop_House_Construction_for_New_Mexico.pdf (accessed May 29, 2012).

Lamont, W.J. 2005. "Plastics: Modifying the Microclimate for the Production of Vegetable Crops." HortTechnology 15(3):477-481.

- 2009. "Overview of the Use of High Tunnels Worldwide." HortTechnology 19(1): 25-29.

Ligon, E. 2011. "Supply and Effects of Specialty Crop Insurance." Research Working Paper 16709, National Bureau of Economic Research, Cambridge, MA.

Median, Y., A. Gosselin, Y. Desjardins, L. Gauthier, R. Harnois, and S. Khanizadeh. 2009. "Effect of Plastic Mulches on Microclimate Conditions, Growth, and Yields of Strawberry Plants Grown under High Tunnels in Northern Canadian Climate." Acta Horticulturae 842: 139-142.

National Agricultural Statistics Service. 2012. "Agricultural Statistics Data Base (Quick Stats), Prices Received Monthly, Strawberries and Tomatoes, 2002-2011, U.S. Total." NASS, USDA, Washington, DC.

National Oceanic and Atmospheric Administration. 2013. "Lubbock Precipitation from 1911-Present." Available at www.srh.noaa.gov/lub/?n=climate-klbb-pcpn (accessed on April 3, 2013)

Natural Resources Conservation Service, USDA. 2011. "USDA Provides Update on Seasonal High Tunnel Pilot" web page. Available at http://sustainableagriculture.net/blog/usdaupdates-high-tunnel-info (accessed January 2011).

Nennich, T.T., and P. Johnson. 2004. "Introduction to High Tunnel Production in Minnesota." Minnesota High Tunnel Production Manual for Commercial Growers. Minneapolis, MN Regents of the University of Minnesota. Available at www.extension.umn.edu/ distribution/horticulture/M1218.html (accessed on September 26, 2012).

Risk Management Agency, USDA. 2004. Report on Specialty Crop Insurance. RMA, USDA, Washington, DC. Available at www.rma.usda.gov/pubs/2004/specialtycrop.pdf (accessed September 26, 2012). 
2012. "Summary of Business Reports and Data" web page. RMA, USDA, Washington, DC. Available at www.rma.usda.gov/data/sob.html (accessed April 3, 2013).

State of Tennessee. 2010. "Tennessee Invests in Community Agricultural Projects." News release, State of Tennessee Newsroom and Media Center, Nashville, TN. Available at https://news.tn.gov/node/5676 (accessed on September 12, 2012).

Wallace, R.W., C. Miles, A. Wszelaki, D.A. Inglis, J. Roozen, J. Martin, and C.J. Webb. 2011. "High Tunnel Lettuce Variety Yield and Quality When Grown in Different U.S. Climates." HortScience 46(10): S154.

Wallace, R.W., A.L. Wszelaki, C.A. Miles, J.S. Cowan, J. Martin, J. Roozen, B. Gundersen, and D.A. Inglis. 2012. "Lettuce Yield and Quality When Grown in High Tunnel and Open-field Production Systems under Three Diverse Climates." HortTechnology 22(5): 659-668.

Waterer, D. 2003. "Yields and Economics of High Tunnels for Production of Warm-season Vegetable Crops." HortTechnology 13(2): 339-343.

World Trade Organization. 2012. "Dispute Settlement: Dispute DS267. United States Subsidies on Upland Cotton." Available at www.wto.org/english/tratop_e/dispu_e/ cases_e/ds267_e.htm (accessed July 28, 2012). 